\title{
Analisis Pengetahuan Peternak dan Evaluasi Keberhasilan Program UPSUS SIWAB di Kecamatan Bayang, Pesisir Selatan
}

\author{
Tinda Afriani, Yurnalis, Firda Arlina, dan Dino Eka Putra \\ Fakultas Peternakan, Universitas Andalas, Kampus Limau Manis, Padang, 25163. Indonesia \\ E-mail: tindaafriani@ansci.unand.ac.id
}

Keywords:

breeder,

evaluation of success,

government, UPSUS SIWAB

Kata Kunci:

evaluasi

keberhasilan,

pemerintah,

peternak, UPSUS SIWAB

\begin{abstract}
UPSUS SIWAB Program is a Special Effort for Obligatory Bovine Cows which is a continuation of the government's program of self-sufficiency in meat. The purpose of this activity was to analyze breeders' knowledge and evaluate the success of the program in Bayang District, Pesisir Selatan Regency. The method used was a survey method with the results of direct interviews, and questionnaires with various community groups, and farmers. Data analysis used descriptive analysis. The result showed that the implementation of the UPSUS SIWAB program in 2018 in Bayang Subdistrict, Pesisir Selatan Regency has not been 100\% implemented. However, the information of this special program was known by farmers, as much as $80 \%$ from the Animal Husbandry Department's counseling and 20\% from fellow breeders. This shows that the counseling or socialization conducted by the government has not reached all farmers in Bayang District. Meanwhile, the results of the performance of this program were the number of acceptors who have been at IB in 2017 (1,213 individuals) and increased by 73\% in 2018 (2,100 individuals). There were the number of Artificial Insemination in 2017 (1,314 times) and increased by 92\% in 2018 (2,526 times), the number of acceptors pregnant in $2017(1,158)$ and decreased by $2 \%$ in $2018(1,136)$, the number of births in 2017 (766) and decreased by 80\% in 2018 (151 tails).
\end{abstract}

\footnotetext{
ABSTRAK

UPSUS SIWAB (Upaya Khusus Sapi Indukan Wajib Bunting) merupakan keberlanjutan proram pemerintah dari program swasembada daging. Tujuan dari kegiatan ini untuk menganalisa pengetahuan peternak dan evaluasi keberhasilan program tersebut. Metode yang digunakan adalah metode survey dengan hasil wawancara langsung, dan kuesioner dengan masyarakat dan peternak. Analisis data menggunakan analisis deskriptif. Hasil kegiatan menunjukkan bahwa pelaksanaan program UPSUS SIWAB tahun 2018 di Kecamatan Bayang, Kabupaten Pesisir Selatan belum $100 \%$ terlaksana, namun informasi program UPSUS SIWAB ini diketahui peternak sebanyak 80\% dari penyuluhan Dinas Peternakan dan 20\% lainnya dari sesama peternak. Hal ini menunjukkan bahwa penyuluhan atau sosialisasi yang dilakukan pemerintah belum menjangkau semua peternak yang ada di Kecamatan Bayang. Sementara itu, hasil capaian kinerja program ini yaitu jumlah akseptor yang telah di IB pada tahun 2017 (1.213 ekor) dan meningkat sebesar 73\% pada tahun 2018 (2.100 ekor). Jumlah Inseminasi Buatan pada tahun 2017 (1.314 kali) dan meningkat sebesar 92\% pada tahun 2018 (2.526 kali). Jumlah akseptor yang bunting pada tahun 2017 (1.158 ekor) dan menurun sebesar 2\% pada tahun 2018 (1.136 ekor), dan jumlah kelahiran pada tahun 2017 (766 ekor) dan menurun sebesar 80\% pada tahun 2018 (151 ekor).
} 


\section{PENDAHULUAN}

Nagari Kapelgam Koto Marapak Bayang, Kabupaten Pesisir Selatan merupakan salah satu nagari di Provinsi Sumatera Barat yang mempunyai sejumlah keunggulan dalam bidang Pertanian dan Peternakan. Nagari ini memiliki populasi ternak sapi potong sebanyak 80.146 ekor pada tahun 2016 dengan jumlah peternak 42 ribu kepala keluarga (KK) yang tersebar di 15 kecamatan yang ada. Nagari ini juga memiliki luas lahan sebesar 733 Ha terdiri dari 158 Ha untuk bagian lahan pertanian sawah irigasi, 455 Ha untuk lahan pertanian nonsawah, $120 \mathrm{Ha}$ untuk lahan peternakan dan 2 aliran sungai yang menjadi sumber air bagi masyarakat yaitu sungai Bayang Sani dan sungai Batang Bayang (Badan Pusat Statistik, 2017).

Pada tahun 2017, populasi ternak sapi potong di Kecamatan Bayang sebanyak 81.786 ekor (Badan Pusat Statistik, 2017). Guna mempercepat pencapaian peningkatan produktivitas dan populasi sapi potong dalam mempertahankan plasma nutfah Sumatera Barat, pemerintah meluncurkan salah satu program UPSUS SIWAB (Upaya Khusus Sapi Indukan Wajib Bunting) (Feradis, 2010; Afriani, 2015)). Program ini bertujuan untuk percepatan peningkatan populasi ternak bunting yang merupakan keberlanjutan dari program swasembada daging dan gertak berahi pada ternak (Kementerian Pertanian, 2017). Target pencapaian UPSUS SIWAB tahun 2017 secara nasional diasumsikan menjadi akseptor (penerima) sebesar 70\% atau setara 4 juta ekor, sementara target kebuntingan yang diperoleh sebesar $73 \%$ atau setara 3 juta ekor (Kementerian Pertanian, 2017).

Pada tahun 2017 hasil dari program UPSUS SIWAB di Kabupaten Pesisir Selatan masih banyak permasalahan dan jauh dari target, yaitu sebanyak 10.481 akseptor Inseminasi Buatan. Sedangkan pada tahun 2018 hingga akhir bulan Juli, yaitu sebanyak 5.777 akseptor dengan angka kebuntingan sebesar 3.844 ekor dan angka kelahiran sebesar 2.122 ekor. Kecamatan Bayang merupakan kecamatan yang berada di Kabupaten Pesisir Selatan. Kecamatan Bayang merupakan daerah kawasan Inseminasi Buatan, dan tempat pertama kalinya pos IB didirikan oleh pemerintah kabupaten Pesisir Selatan yang mulai dioperasikan pada tahun 1994. Berdasarkan hal tersebut Program UPSUS SIWAB yang dibuat pemerintah sebaiknya dapat memberikan pengaruh baik kepada masyarakat dan kalangan peternak, guna mengatasi masalah peningkatan kebutuhan daging impor.

\section{METODE}

Kegiatan ini dilaksanakan di Kecamatan Bayang Kabupaten Pesisir Selatan. Beberapa tahapan yang dilakukan meliputi :

\section{Survei Lokasi, Persiapan dan Pembekalan}

Survei lokasi dilakukan diawal kegiatan, tujuannya adalah untuk mengidentifikasi permasalah utama yang dihadapi oleh masyarakat berbagai kalangan, dan peternak di Nagari Kapelgam Koto Marapak, Kecamatan Bayang, kemudian melihat respon masyarakat terhadap rencana kegiatan dan program yang akan dilaksanakan (Syaiful dkk, 2018). Persiapan yang dilakukan berkaitan dengan bahan dan peralatan serta waktu dan tempat pelaksanaan kegiatan.

\section{Populasi}

Jumlah peternak dalam program UPSUS SIWAB di Kecamatan pada tahun 2018 sebanyak 916 orang peternak, dengan jumlah akseptor sebanyak 2100 ekor. Jumlah peternak tahun 2018 merupakan populasi di dalam kegiatan ini.

\section{Teknik Pengumpulan Sampel}

Teknik pengumpulan sampel dilakukan secara quota sampling yaitu menetapkan 50 orang peternak sebagai sampel dengan jumlah akseptor 100 ekor. 


\section{Penyuluhan}

Metode pelaksanaan kegiatan ini menggunakan metode penyuluhan, sosialisasi dan survei dengan pengumpulan data dari responden yang terdiri dari Dinas Peternakan dan Kesehatan Hewan, Kabupaten Pesisir Selatan. Wawancara dengan semua kalangan masyarakat, dan peternak di Kecamatan Bayang (Syaiful dkk, 2018).

\section{Analisis Data}

Analisis data dilakukan secara deskriptif dengan melihat tingkat pengetahuan peternak dan evaluasi tingkat keberhasilan IB dalam program UPSUS SIWAB tahun 2018 di Kecamatan Bayang Kabupaten Pesisir Selatan.

\section{HASIL DAN PEMBAHASAN}

\section{Karakteristik Responden}

Hasil kegiatan pemberdayaan masyarakat ini, mengenai karakteristik responden di Kecamatan Bayang Kabupaten Pesisir Selatan ditunjukkan pada Tabel 1.

Tabel 1. Karakteristik Peternak di Kecamatan Bayang Kabupaten Pesisir Selatan

\begin{tabular}{|c|c|c|c|c|}
\hline No & Kategori & Indikator & $\begin{array}{c}\text { Jumlah } \\
\text { Responden }\end{array}$ & Persentase (\%) \\
\hline \multirow[t]{3}{*}{1} & Umur & $<25$ & 1 & 2 \\
\hline & & $25-55$ & 41 & 82 \\
\hline & & $>55$ & 8 & 16 \\
\hline \multirow[t]{5}{*}{2} & Pendidikan & Tidak ada & 1 & 2 \\
\hline & & SD & 7 & 14 \\
\hline & & SLTP/sederajat & 18 & 36 \\
\hline & & SMU/sederajat & 23 & 46 \\
\hline & & Perguruan Tinggi & 1 & 2 \\
\hline \multirow[t]{3}{*}{3} & Pengalaman beternak & $<5$ Tahun & 9 & 18 \\
\hline & & 5-10 Tahun & 20 & 40 \\
\hline & & $>10$ Tahun & 21 & 42 \\
\hline \multirow[t]{3}{*}{4} & Polapemeliharaan yang & Intensif & 39 & 78 \\
\hline & diterapkan & Semi intensif & 10 & 20 \\
\hline & & Ekstensif & 1 & 2 \\
\hline
\end{tabular}

\section{Sumber Informasi Peternak Tentang Program UPSUS SIWAB}

Dalam melaksanakan program pemerintah UPSUS SIWAB, diperlukan adanya kerjasama dan partisipasi dari masyarakat khususnya peternak dalam hal pencapaian sasaran dan tujuan. Program kerja pemerintah ini tidak dapat terealisasikan dengan maksimal tanpa adanya sosialisasi ke masyarakat (Raharjo, 2011). Hasil kegiatan pemberdayaan masyarakat mengenai sumber informasi peternak tentang program UPSUS SIWAB, ditunjukkan pada Tabel 2.

Berdasarkan data Tabel 2. diketahui bahwa peternak yang mengetahui program UPSUS SIWAB dari penyuluhan Dinas Peternakan adalah sebanyak 80\%. Sedangkan 20\% lainnya mengetahui program UPSUS SIWAB dari sesama peternak. Hal ini menunjukkan bahwa sosialisasi ataupun penyuluhan yang dilakukan pemerintah belum menjangkau semua peternak yang ada di Kecamatan Bayang Kabupaten Pesisir Selatan.

Intensitas pertemuan dalam penyuluhan ini dilakukan 1 kali untuk 90\% peternak yang menjadi responden, dan 10\% lainnya mendapat penyuluhan sebanyak 2 kali. Intensitas penyuluhan sangat penting dilakukan guna proses adopsi teknologi. Semakin tinggi frekuensi penyuluhan, maka keberhasilan penyuluhan yang disampaikan akan semakin tinggi pula. Metode pelaksanaan penyuluhan sebagian besar dilakukan dari kandang ke kandang yaitu 60\%, 20\% 
dilakukan dari rumah kerumah, dan 20\% lainnya dilakukan dengan cara mengumpulkan peternak pada suatu tempat.

Tabel 2. Sumber Informasi Peternak Tentang Program UPSUS SIWAB

\begin{tabular}{|c|c|c|c|c|}
\hline No & Kategori & Indikator & $\begin{array}{c}\text { Jumlah } \\
\text { Responden }\end{array}$ & $\begin{array}{l}\text { Persentase } \\
\quad(\%)\end{array}$ \\
\hline \multirow[t]{3}{*}{1} & $\begin{array}{l}\text { Sumber peternak } \\
\text { mengetahui adanya }\end{array}$ & $\begin{array}{l}\text { a. Dari penyuluhan Dinas } \\
\text { Peternakan }\end{array}$ & 40 & 80 \\
\hline & $\begin{array}{l}\text { program } \\
\text { UPSUS SIWAB }\end{array}$ & $\begin{array}{l}\text { b. Dari Sosialisasi perguruan } \\
\text { tinggi UNAND }\end{array}$ & 0 & 0 \\
\hline & & c. Dari sesama peternak & 10 & 20 \\
\hline \multirow[t]{3}{*}{2} & Jumlah pertemuan & a. 1 kali & 36 & 90 \\
\hline & penyuluhan Dinas & b. 2 kali & 4 & 10 \\
\hline & Peternakan & c. Lebih dari 2 kali & 0 & 0 \\
\hline \multirow[t]{3}{*}{3} & Metode pelaksanaan & a. Dari rumah ke rumah & 8 & 20 \\
\hline & penyuluhan tersebut & $\begin{array}{l}\text { b. Peternak dikumpulkan pada } \\
\text { satu tempat }\end{array}$ & 8 & 20 \\
\hline & & c. Dari kandang ke kandang & 24 & 60 \\
\hline
\end{tabular}

\section{Pemahaman Peternak Tentang Program UPSUS SIWAB}

Hasil kegiatan pemberdayaan masyarakat mengenai pemahaman peternak tentang program UPSUS SIWAB ditunjukkan pada Tabel 3.

Tabel 3. Pemahaman Peternak Tentang Program UPSUS SIWAB

\begin{tabular}{lllcc}
\hline \multirow{2}{*}{ No } & \multicolumn{1}{c}{ Kategori } & \multicolumn{1}{c}{ Indikator } & $\begin{array}{c}\text { Jumlah } \\
\text { Responden }\end{array}$ & $\begin{array}{c}\text { Persentase } \\
(\%)\end{array}$ \\
\hline 1 & Pemahaman peternak & a. Sangat paham & 17 & 34 \\
& terhadap penyuluhan & b. Cukup paham & 27 & 54 \\
& program UPSUS SIWAB & c. Kurang paham & 6 & 12 \\
& & d. Tidak paham & 0 & 0 \\
\multirow{2}{*}{2} & Pemahaman peternak & a. Sangat paham & 20 & 40 \\
& tentang ciri-ciri ternak & b. Cukup paham & 28 & 56 \\
& sapi/kerbau yang birahi & c. Kurang paham & 2 & 4 \\
& & d. Tidak paham & 0 & 0 \\
\hline
\end{tabular}

Dari Tabel 3. diketahui bahwa 34\% peternak yang sangat paham terhadap penyuluhan program UPSUS SIWAB dan 54\% peternak lainnya cukup paham, sedangkan peternak yang kurang paham adalah sebanyak 12\%. Hal ini menunjukkan bahwa sebagian besar peternak sudah paham dengan penyuluhan program UPSUS SIWAB. Sementara itu untuk ciri-ciri ternak sapi atau kerbau yang berahi, 40\% peternak menjawab sangat paham dan 56\% lainnya menjawab cukup paham. Sedangkan 4\% lainnya menjawab kurang paham.

Peningkatan pengetahuan peternak dalam hal deteksi berahi sangat penting dilakukan karena dapat mempengaruhi keberhasilan IB. Oleh karena itu peternak harus mengetahui gejala, tingkah laku dan tanda-tanda berahi pada ternak sehingga IB dapat dilakukan pada waktu yang tepat dengan ahli inseminator yang berpengalaman (Ma'sum dkk, 2012). 


\section{Hasil Pelaksanaan IB dalam Program UPSUS SIWAB}

Beberapa faktor yang mempengaruhi keberhasilan Inseminasi Buatan (IB), yaitu kualitas semen pejantan, kesuburan betina, keterampilan inseminator, pengetahuan peternak, keterampilan peternak dalam mendeteksi berahi ternaknya, ketepatan waktu inseminasi, serta komunikasi antara peternak dengan inseminator (Ariani, 2015; Ismaya, 2014). Berdasarkan hasil kegiatan pemberdayaan masyarakat ini diketahui bahwa $20 \%$ responden sangat paham ciri-ciri ternak yang berahi, 28\% cukup paham dan 2\% lainnya kurang paham. Hal ini menunjukkan bahwa sebagian besar peternak sudah paham dengan ciri-ciri ternak yang berahi. Sedangkan untuk komunikasi terhadap inseminator, sebanyak $100 \%$ responden menghubungi inseminator pada saat tanda-tanda berahi ternak terdeteksi (Direktorat Jenderal Peternakan dan Kesehatan Hewan, 2012). Hal ini menunjukkan bahwa peternak sudah paham langkah yang harus dilakukan pada saat tanda-tanda berahi pada ternak terdeteksi

Hasil kegiatan pemberdayaan masyarakat tentang pelaksanaan dan hasil IB ditunjukkan pada Tabel 4 .

Tabel 4. Hasil Pelaksanaan IB di Kecamatan Bayang Kabupaten Pesisir Selatan

\begin{tabular}{clcc}
\hline No & \multicolumn{1}{c}{ Indikator } & Tahun 2017 & Tahun 2018 \\
\hline 1 & $\begin{array}{l}\text { Jumlah inseminasi yang sudah } \\
\text { dilakukan }\end{array}$ & 1314 & 2526 \\
2 & $\begin{array}{l}\text { Jumlah inseminasi 1 yang sudah } \\
\text { dilakukan }\end{array}$ & 1213 & 2100 \\
3 & $\begin{array}{l}\text { Jumlah inseminasi 2 yang sudah } \\
\text { dilakukan }\end{array}$ & 88 & 336 \\
4 & Jumlah inseminasi 3 yang sudah & 13 & 90 \\
& dilakukan & 1158 & 1136 \\
5 & Angka kebuntingan ternak hasil IB & 1069 & 944 \\
6 & Angka kebuntingan ternak hasil IB 1 & 78 & 151 \\
7 & Angka kebuntingan ternak hasil IB 2 & 11 & 806 \\
8 & Angka kebuntingan ternak hasil IB 3 & 766 & \\
9 & Realisasi kelahiran ternak hasil IB di & & \\
& Kecamatan Bayang &
\end{tabular}

Berikut beberapa dokumentasi tentang sosialisasi, dan tingkat pengetahuan peternak serta evaluasi keberhasilan IB dalam program UPSUS SIWAB yang terdiri dari beberapa program kegiatan.

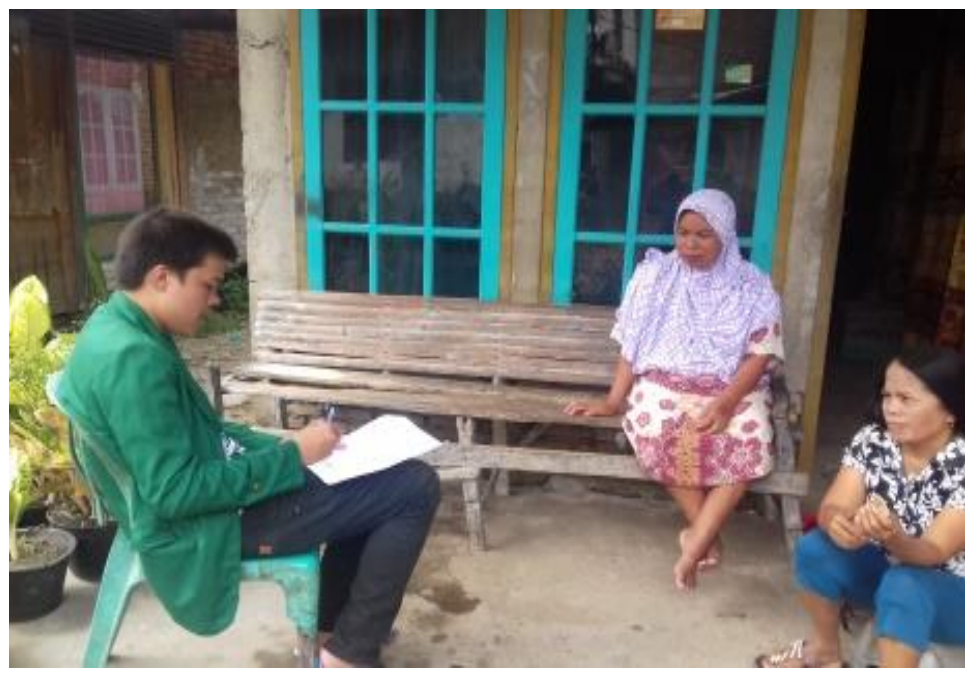

Gambar 1. Kegiatan Identifikasi Jumlah Populasi Ternak 


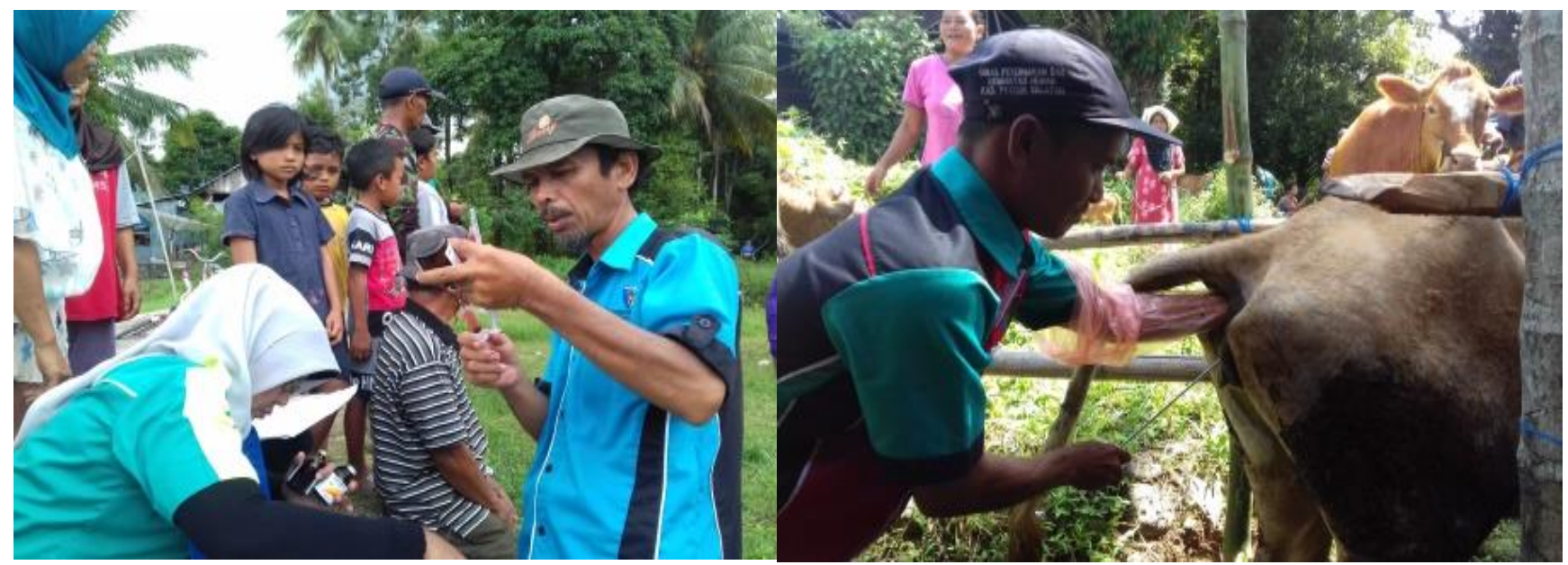

Gambar 2. Pelaksanaan Program UPSUS SIWAB; Sinkronisasi Estrus (kiri), Inseminasi Buatan (kanan)

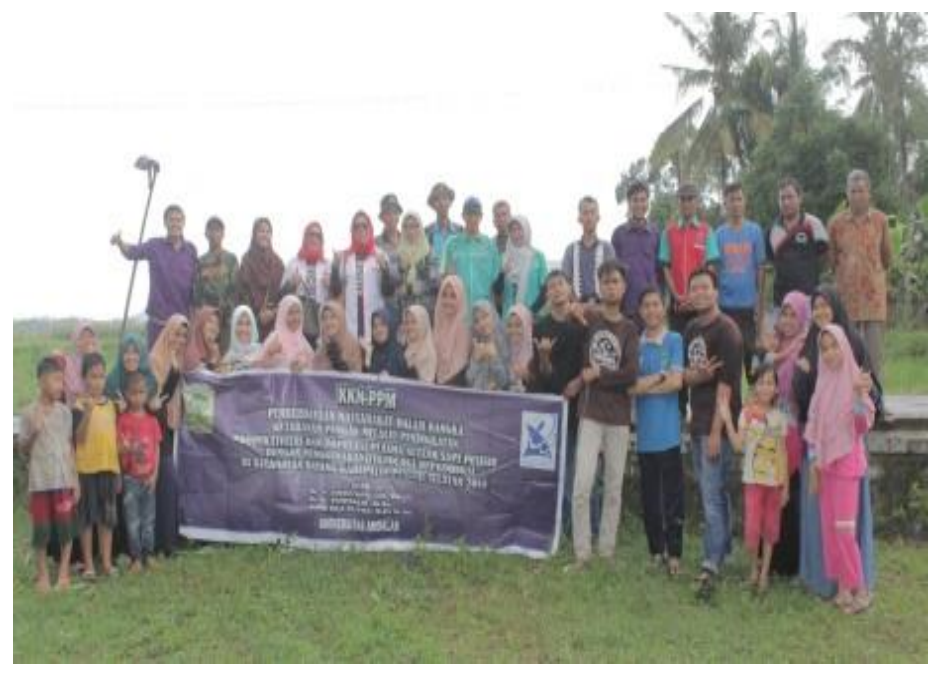

Gambar 3. Pelayanan Kesehatan Hewan

\section{KESIMPULAN}

Berdasarkan penelitian yang dilakukan dapat disimpulkan bahwa pelaksanaan program UPSUS SIWAB di Kecamatan Bayang, Kabupaten Pesisir Selatan tahun 2018 belum terlaksana 100\%. Hasil Kegiatan program UPSUS SIWAB adalah jumlah akseptor yang telah di IB pada tahun 2017 (1.213 ekor) dan meningkat sebesar 73\% pada tahun 2018 (2.100 ekor), jumlah inseminasi buatan yang telah dilakukan pada tahun 2017 (1.314 kali) dan meningkat sebesar 92\% pada tahun 2018 ( 2.526 kali), jumlah akseptor yang bunting pada tahun 2017 (1.158 ekor) dan menurun sebesar 2\% pada tahun 2018 (1.136 ekor), jumlah kelahiran pada tahun 2017 (766 ekor) dan menurun sebesar 80\% pada tahun 2018 (151 ekor).

Dalam pelaksanaan program UPSUS SIWAB diharapkan pemerintah dan semua kalangan terkait mampu mengevaluasi pencapaian dari program UPSUS SIWAB yang dilaporkan. Pihak terkait harus menindaklanjuti kegiatan program yang tidak berjalan sebagaimana mestinya, agar tujuan dan target dari program UPSUS SIWAB dapat tercapai sesuai yang diharapkan. 


\section{UCAPAN TERIMA KASIH}

Tim pelaksana kegiatan mengucapkan terimakasih kepada Direktorat Riset dan Pengabdian Masyarakat, Direktorat Jendral Penguatan Riset dan Pengembangan, Kementerian Riset, Teknologi dan Pendidikan Tinggi sesuai dengan perjanjian Penugasan Pelaksanaan Program Pengabdian Kepada Masyarakat, Nomor: 001/SF2H/PPM/DRPM/2018, tanggal 30 Januari 2018 Tahun Anggaran 2018. Universitas Andalas yang telah mempercayakan pada kami untuk melaksanakan kegiatan ini, serta menfasilitasi artikel kegiatan sampai dipublikasi.

\section{DAFTAR PUSTAKA}

Afriani, T. 2015. Penerapan teknologi reproduksi pada sapi. Padang: Andalas University Press.

Badan Pusat Statistik. 2017. Populasi ternak provinsi Sumatera Barat menurut Kabupaten/Kota Tahun 2013-2017.

Direktorat Jenderal Peternakan dan Kesehatan Hewan. 2012. Pedoman optimalisasi Inseminasi Buatan (IB). Jakarta: Kementerian Pertanian RI.

Ediset, E. Harianto dan A. Anas. 2018. 'Perbaikan usaha peternakan sapi pada aspek pakan di nagari Siguntur Kecamatan Sitiung, Dharmasraya', Buletin Ilmiah Nagari Membangun, 1(4), hal.139-145.

Feradis. 2010. Bioteknologi reproduksi pada ternak. Bandung: Alfabeta.

Kementerian Pertanian. 2017. Inovasi teknologi peternakan mendukung SIWAB. Kementerian Pertanian, Bogor.

Ismaya. 2014. Bioteknologi Inseminasi Buatan pada sapi dan kerbau. Yogyakarta: Gadjah Mada University Press.

Ma'sum, M., A.V.S. Hubeis., A. Saleh., dan B. Suharjo. 2012. 'Persepsi peternak tentang penerapan Inseminasi Buatan di tiga sentra sapi potong di Indonesia', Jurnal Penyuluhan, 8(1), hal.5556.

Raharjo, A. 2011. Manajemen pemerintahan daerah. Yogyakarta: Geraha Ilmu.

Sidik, F. 2015. 'Menggali potensi lokal mewujudkan kemandirian desa', Jurnal Kebijakan dan Administrasi Publik, 19(2), hal.116-120.

Syaiful, F.L., U.G.S. Dinata dan F. Ferido. 2018. 'Pemberdayaan masyarakat Nagari Sontang Kabupaten Pasaman melalui inovasi budidaya sapi potong dan inovasi pakan alternatif yang ramah lingkungan', Buletin Ilmiah Nagari Membangun, 1(3), hal.21-31.

Yusuf. 2010. Kompetensi peternak dalam pengelolaan usaha sapi potong di Kabupaten Konawe Provinsi Sulawesi Tenggara. Institut Pertanian Bogor, Bogor. 